\title{
EFFECTS OF CATALYSTS ON EMISSIONS OF POLLUTANTS FROM COMBUSTION PROCESSES OF LIQUID FUELS
}

\author{
Agnieszka BOK ${ }^{1}$, Joanna GUZIAŁOWSKA-TIC, Wilhelm Jan TIC \\ Opole Technical University, Department of Environmental Engineering, Poland
}

\begin{abstract}
The dynamic growth of the use of non-renewable fuels for energy purposes results in demand for catalysts to improve their combustion process. The paper describes catalysts used mainly in the processes of combustion of motor fuels and fuel oils. These catalysts make it possible to raise the efficiency of oxidation processes simultanously reducing the emission of pollutants. The key to success is the selection of catalyst compounds that will reduce harmful emissions of combustion products into the atmosphere. Catalysts are introduced into the combustion zone in form of solutions miscible with fuel or with air supplied to the combustion process. The following compounds soluble in fuel are inclused in the composition of the described catalysts: organometallic complexes, manganese compounds, salts originated from organic acids, ferrocen and its derivatives and sodium chloride and magnesium chloride responsible for burning the soot (chlorides). The priority is to minimize emissions of volatile organic compounds, nitrogen oxides, sulphur oxides, and carbon monoxide, as well as particulate matter.
\end{abstract}

Keywords: air pollution, environmental protection, emission of pollutants, metallic catalyst, particulate matter, soot

\footnotetext{
${ }^{1}$ Corresponding author: Opole Technical University, Department of Environmental Engineering, ul. St. Mikołajczyka 5, 45-271 Opole, Poland; e-mail: a.bok@ doktorant.po.edu.pl, tel. +48774498390
} 


\section{INTRODUCTION}

To keep the environmental balance is the main role of sustainable coexistence between the plurality of wild-living species. That is why any situations leading to its disturbance should be minimized. Therefore, it is necessary to control mining and manufacturing processes leading to the formation of any kind of pollution. The optimal solution is to prevent the origin of pollutants without entering or interference with any life realms. Anthropogenic factors have the biggest impact on the negative changes in the environment. Man mines fossil fuels and tries to use them to achieve the best energy performance.

The contrast between population growth and the inevitable depletion of fossil fuels has caused a shift towards a more efficient use of fuel economy. Public authorities on behalf of the citizens are obliged to protect the environment and prevent the negative health consequences of environmental degradation The Constitution requires the state to care for the environment and take responsibility for the deterioration caused [1].

Science - especially chemistry-related fields - industrial as well as physiological processes - has a significant impact on industrial development. It is possible to obtain "zero emission", but it often makes available technology useless under free market conditions. Currently in the power industry, fuels are used in various states of matter, an increasingly important role is played by liquid fuels. Organic fractions caused by rectification of crude oil are meant. Rectification carried out as a mass process in refineries does not allow to get "clean" products. Light fractions derived from crude oil: petrol, diesel, are used directly as fuel in combustion processes. Heavy fractions such as: fuel oils, mazouts, asphaltenes are nowadays more and more often used as fuels, or undergo the cracking process, which produces hydrocarbons with shorter carbon chains, such as those occurring in gasoline and diesel fuel.

In recent years a significant increase in the production of fuels was observed especially in the case of diesel fuel and heavy fuel oils. Fig. 1 shows the volume of production of liquid fuels in Poland in the years 2009-2011, including the distinction between individual fractions of fuel.

Production of heavy fuel oils totalled in 2011 at over 2.9 million cubic meters an increase of $68 \%$ compared to 2009 . This tendency is explained not only by the increased crude oil processing in refineries, but also by the national launch of new ones and the modernization of existing processing plants. In the case of diesel fuel within two years, production has increased by about 15\% [3]. 
The upward trend in production is associated with an increase in the processing of crude oil in the refineries and the launch of new and existing processing plants.

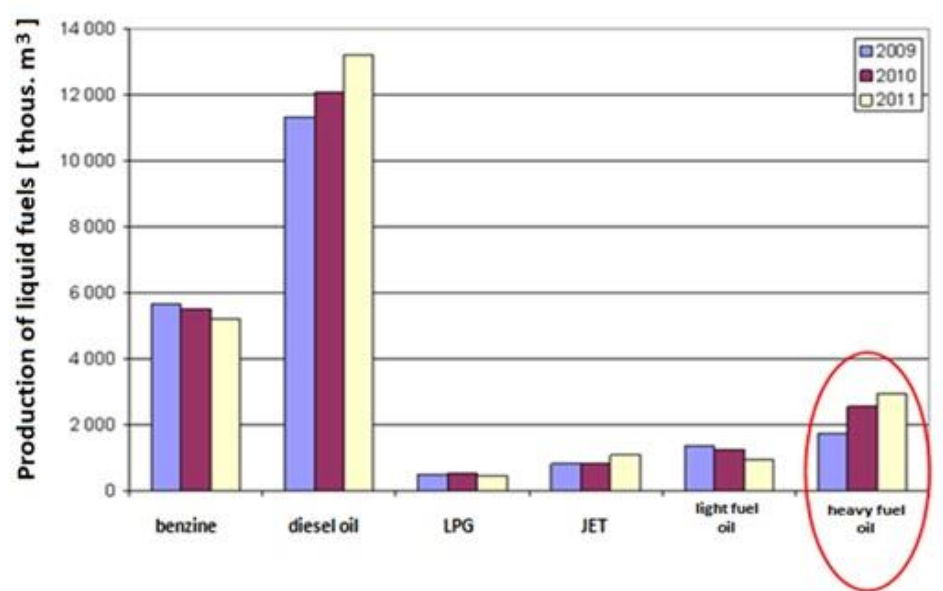

Fig 1. Comparison of the production of liquid fuels in the years 2009-2011, in thousands of $\mathrm{m}^{3}$ [2]

\section{CHARACTERISTICS OF HAZARDOUS BY-PRODUCTS OF FUEL COMBUSTION}

Production of energy in the process of burning fuels generates pollution, which has a negative impact on the environment. The desired effect of the combustion process involves the production of an utilitarian value using a selected path of conversion. By-products, including gases containing significant quantities of environmentally harmful, noxious gases emerge from the combustion process. Human unawareness of these unwanted products causes their uncontrolled emission into the atmosphere. Air pollutants, in accordance with Annex II of the Directive on industrial emissions, are included in the following groups of chemical compounds [4]:

1. Sulfur dioxide and other sulfur compounds

2. Nitrogen oxides and other nitrogen compounds

3. Carbon monoxide

4. Volatile organic compounds (VOCs)

5. Metals and their compounds

6. Dust and fine particulate matter

7. Asbestos - suspended particulates, fibers 
8. Chlorine and its compounds

9. Fluorine and its compounds

10. Arsenic and its compounds

11. Cyanide

12. Substances and mixtures which have been proved to possess carcinogenic or mutagenic properties or due to inhalation show teratogenic properties

13. Polychlorinated dibenzodioxins and polychlorinated dibenzofurans.

The most harmful components of engine exhaust include nitrogen oxides, carbon monoxide, hydrocarbons, particulate matter and sulfur oxides. Nitrogen oxides are toxic components of the gases from the combustion of fuels derived primarily from the oxidation of atmospheric nitrogen. The rate of formation of nitrogen oxides depends primarily on flame temperature and the excess air ratio. In this group there are: nitrous oxide, nitric oxide, nitrogen dioxide, nitrogen trioxide, nitrogen tetroxide and nitrogen pentoxide. In general, a group of these compounds forms fairly strong oxidizing agents, in terms of relatively high reactivity effects on living organisms. In the case of carbon monoxide - toxic product of incomplete oxidation - high concentration in inhaled air causes body hypoxia, with the following symptoms: headache, dizziness, fatigue, loss of appetite, sleep disturbances. Polycyclic hydrocarbons (PAHs) include a wide variety of aromatic substances composed of two or more benzene rings or cyclopentadiene. In the case of over-exposure to PAHs, nausea, dizziness, loss of consciousness, organ damage and bone marrow vessels may occur [5]. Particulate matter (PM) is a product with the consistency of liquid or solid, that is, containing inter alia carbon, sulfur and nitrogen, either heavy metals and hydrocarbons. Most harmful particles due to their physical and chemical properties - due to their size, the particles of PM are easily absorbed by living organisms, and with them harmful substances. The harmfulness of PM depends on its aerodynamical diameter - soot may constitute up to $30 \%$ of its weight. Soot is harmful because it can adsorb on the surface of its main component amorphous carbon - other very toxic substances (e.g. BaP). Breathing air containing carbon black can cause all sorts of diseases of the respiratory system, cardiovascular system and may generate tumors. Sulfur oxides can be treated as sulfuric acid anhydrides. Sulfur dioxide is toxic to animals and harmful to plants.

The quantity and quality of gases produced during combustion depends not only on the quality of fuel but also on the conditions under which combustion takes place. However, treating the access of oxidant to the combustion chamber as a major criterion, the emissions arising from the incineration of hazardous gases, such as carbon oxides, nitrogen oxides, sulfur oxides, polycyclic aromatic hydrocarbons (including pyrene) and dust can not be clearly defined. The 
emission of these compounds is regulated by law. Limits on emissions of these hazardous substances into the environment are strictly regulated by the act of 27 April 2001. Environmental Law and the implementing legislation for this act [6]. The EU also clearly defines the acceptable levels for emissions of exhaust gases from industrial plants.

In March 2008 the leaders of the European Union Member States took a decisive action to prevent climate change. They created the scenario of " $3 \times$ 20\%" - The European Climate and Emission Package - which implies the need for:

- reduction of carbon dioxide emissions by $20 \%$ by 2020 compared to the emissions in 1990,

- improving energy efficiency by $20 \%$ in the same period,

- increasing the share of renewable energy in the total output of energy production also up to $20 \%$ [7].

The principle of "think globally - act locally" to airprotection is reflected in the Land Use Act, which directly affects the distribution of point sources of pollution of anthropogenic origin. The directive of the European Parliament of 24 November 2010 on industrial emissions for the prevention and control of pollution arising from industrial activities is aimed at reducing anthropogenic pollution as far as possible in accordance with the role "polluter pays" [4].

The European emission standards (EURO) introduced in 2000 include emission limit values for pollutants generated by heavy motor vehicles - Table 1 [8]:

Table 1 Emission limit values of individual components in the EURO standards $[\mathrm{g} / \mathrm{km}]$

\begin{tabular}{|c|c|c|c|c|c|c|}
\hline & EURO I & EURO II & EURO III & EURO IV & EURO V & EURO VI \\
\hline CO & 4.5 & 3 & 2.1 & 1.5 & 1.5 & 1.5 \\
\hline HC & 1.1 & 0.95 & 0.66 & 0.46 & 0.46 & 0.13 \\
\hline NOx & 8 & 7.2 & 5 & 3.5 & 2 & 0.4 \\
\hline PM & 0.36 & 0.14 & 0.1 & 0.02 & 0.02 & 0.01 \\
\hline
\end{tabular}

In accordance with the guidelines, diesel engines under the laid down conditions may not exceed the emission limit values set out in Table 1. These standards apply at first to producers who want to sell their vehicles on the European market [8]. After the introduction of Euro III guidelines, the policy of limiting the harmful gases of vehicle exhaust became stricter and further versions of the standard were implemented.

At present, emissions of nitrogen oxides, hydrocarbons, carbon monoxide and particulate matter are regulated for most vehicles: cars, trucks, buses, trains, tractors and agricultural machinery, barges, planes and ships. Vehicles which do not comply with the emission standards cannot be sold in the EU, but 
the latest standards do not apply to older generation vehicles. In determining of new standards generally available technology will be taken into account. This is a necessary step because the results of the previously used duty cycles do not correspond to the real values of the emission occurring during the use of vehicles on the road. In 2011, standards of EURO V emissions were introduced - this has resulted the withdrawal of several engine models from the European market. The result is the implementation of more expensive systems whose aim is the reduction of harmful compounds.

The introduction of the Euro VI standard on 31 December 2013 is associated with a further reduction of nitrogen oxides, particulate matter and hydrocarbons. Emission of nitrogen oxides will be tightened in comparision to the Euro V standard by $80 \%$ while reduction of PM will amount to $66 \%$ [8].

An increase in the production of fuels associated with an increase in population needs and power technologies applied currently relies increasingly on the use of light and heavy fuel oils. These products do not burn easily and, in a way, completely. The amount of undesirable by- products of the combustion process of the above- mentioned fuels emitted into the atmosphere, and the ability to improve the efficiency of combustion determine the need to invent catalists enhancing the combustion process.

Catalysts of environmental protection are used primarily in combustion processes on an industrial scale e.g. engines, boilers, waste incinerators and chemical plants and refineries.

\section{CATALYSTS OF ENVIRONMENTAL PROTECTION}

One of the main purposes of the application of catalysts of environmental protection is the enhanced combustion of liquid hydrocarbons and reduced emission of air pollutants. The key to success is to obtain a catalyst composition which has the ability to reduce particulate emission as well as degradation of unburned hydrocarbons during fuel combustion.

Under the term "liquid hydrocarbons", heavy crude oil fractions are meant, e.g. heavy fuel oils, lubricants, diesel oil, transformer oil, kerosene, aviation fuel, paste (lubricants) and asphaltenes. Chemical compounds that affect the combustion process are introduced as solutions miscible in the fuel, in the specified amounts for the liquid fuel or air introduced into the combustion process. Catalysts in this area can be described in following groups:

1. Fuel additives containing one or more organometallic complexes, which are soluble in oil.

2. Catalysts consisting of a modifier improving combustion, which includes at least one fuel soluble manganese compound. 
3. Chemical compounds used as solutions miscible with the fuel, applied to the liquid fuel or the combustion air in specified amounts - mainly salts of organic acids.

4. Modyfiers consisting of compounds selected from the group of ferrocene and its derivatives.

5. Catalysts for soot combustion.

The first group includes compositions of complexes of alkali metals or rare earth metal constituting the catalyst used in the process of combustion of liquid hydrocarbon fuels with the ability to reduce the concentration of solid particles and the amount of unburned hydrocarbons in the exhaust gases from the combustion of diesel fuel and heavy fuel oils. These fuels burned in diesel engines emit harmful particles of a small size. Particulate matter is a significant source of atmospheric pollution so it is important to degrade it during the combustion process. A substabtial problem is also incomplete combustion causing emissions of unburnt hydrocarbons into the atmosphere and leading to the formation of soot. The use of alkali metals as catalysts reduces the secretion of soot, but for diesel engines rare earth metals are more appropriate to reduce particulate emissions.

In that catalyst composition the liquid carrier is an aromatic solvent and the metal content is from 0.1 to $50 \%$ by weight.

Combusted fuel contain catalyst in an amount of:

- sufficient: 0.1 - $500 \mathrm{ppm}$ of metal (M),

- favorable:0.1 - $100 \mathrm{ppm} \mathrm{M}$,

- most advantageous: $0.5-50 \mathrm{ppm} \mathrm{M}$.

The use of this catalyst is to reduce emissions of particulate matter and unburned hydrocarbons also to control the emission of exhaust gases, and to clean and remove the soot and carbon deposits resulting from partial combustion. Elemental analysis of the composition of exemplary metal complexes used for the combustion of liquid fuels is presented in Table 2 [9].

Table 2 Elemental analysis of the resulting complex of strontium and calcium.

\begin{tabular}{|c|c|c|}
\hline Element & $\begin{array}{c}\text { Complex of strontium } \\
(\mathrm{M}=797 \mathrm{u})\end{array}$ & $\begin{array}{c}\text { Complex of calcium } \\
(\mathrm{M}=635 \mathrm{u})\end{array}$ \\
\hline metal - \%M & $10.99(\mathrm{Sr})$ & $6.7(\mathrm{Ca})$ \\
\hline carbon $-\% \mathrm{C}$ & 56.14 & 60.16 \\
\hline hydrogen $-\% \mathrm{H}$ & 8.70 & 9.71 \\
\hline nitrogen - \% & 10.30 & 8.28 \\
\hline
\end{tabular}

Combustion tests showed that those modifiers reduced fuel opacity by $44 \%$ in the case of strontium catalyst, and by $67 \%$ when calcium was used in the 
catalyst. The smoke emission tests used in the European diesel standard statutory CEC RO3-A84. The issue for the catalyst particulate under the strontium concentration of $10 \mathrm{ppm}$ in the fuel was reduced by $15.5 \%$ and the reduction of hydrocarbon emissions to the metal concentration under these conditions was $6.8 \%$ [9].

Another group of catalysts includes soluble in fuel manganese carbonyl compounds composed with a surfactant containing a hydroxide or an alkaline earth element, ashless dispersant and optionally an emulsifier soluble in fuel. Catalysts belonging to this group contain at least one manganese carbonyl compound soluble in fuel. A manganese carbonyl compound used as an ingredient of the catalyst composition is often cyclopentadienyl manganese tricarbonyl (CMT). This catalyst introduced into the subject of combustion - to any light fuel oil - in an amount of $0.025 \%$ results in a significant improvement in the reduction of soot. The use of CMT in pure form or in the form of composed fuel mixtures for combustion of diesel fuel and marine residual oil causes reduction of carbonaceous deposits in the inlet valve (it does not apply to other surfaces of the combustion chamber) and also reduces the smoke.

The addition of a catalyst having the composition specified in Table 3 in the quantity of $400 \mathrm{ppm}$ caused as a result of diesel combustion tests on the Mercedes - Benz engine (engine tests were conducted using a MercedesBenz OM 364 A 4-liter, four-cylinder) a reduction of the emission of hydrocarbons from 0.627 to $0.527 \mathrm{~g} / \mathrm{HPh}[10]$.

Table 3 The composition of the tested manganese modifier [10]

\begin{tabular}{|c|c|}
\hline$[\%]$ & Ingredient \\
\hline 4.5 & $\begin{array}{c}\text { MMT blend: } 68 \% \text { methylcyclopentadienyl manganese tricarbonyl and } \\
38 \% \text { aromatic solvent }\end{array}$ \\
\hline 33.0 & overbased calcium sulphonate blend \\
\hline 22.7 & $\begin{array}{l}\text { polyisobutenyl succinimide of tetraethylene pentamine as a } 23 \% \\
\text { solution in a solvent oil }\end{array}$ \\
\hline 6.8 & demulsifier (TOLAD 286K) \\
\hline 33.0 & heavy aromatic naphtha diluent \\
\hline
\end{tabular}

A decrease in emissions was also observed in the case of particulate matter from the amount of $0.3574 \mathrm{~g} / \mathrm{HPh}$ to $0.3063 \mathrm{~g} / \mathrm{HPh}$. These results were achieved, however, no significant improvement in the emissions of $\mathrm{NO}_{\mathrm{x}}$ and $\mathrm{CO}_{2}$ was noticed. The test results indicated that the proposed fuel invention generally possessed enhanced combustion properties: less smoke, lower soot acidity and opacity and better thermal stability. Furthermore, the use of this invention results in the formation of reduced amounts of sludge deposits on critical engine or burner parts or surfaces. Such fuels tend to emitt not only lower amounts of 
$\mathrm{NO}_{\mathrm{x}}$, but they result in reduced corrosion tendencies with minimal interference with other desirable fuel properties. Those results also indicate that this invention can result in decreased fuel consumption in diesel engines.

For chemical compounds which improve the combustion process are solutions miscible with the liquid fuel in specified amounts in relation to the fuel or air supplied to the combustion chamber. This group of compounds includes [11]:

- salts of organic acids including naphtenates, octoates, tallates, salts of sulfonic acids, saturated or unsaturated fatty acids including oleic acids, tall oil,

- metals selected from the group of: potassium, barium, magnesium, calcium, cerium, manganese, iron; rare earth metals (REEs),

- organometallic compounds including carbonyl compounds, mixed cyclopentadienylcarbonyl compounds or aromatic complexes of the transition metals: iron or manganese.

In order to minimize the content of $\mathrm{NO}_{\mathrm{x}}$ in exhaust gases and using economically justified chemicals, defined amounts of reducing agent are introduced into the firebox by way of a boiler metering system in a liquid or gaseous carrier stream. An aqueous solution of urea or urea in the form of a precursor of ammonia or ammonium carbonate is used as a fluid carrier stream, which may also contain additional components, such as alcanols, alkanecarboxylic acids, alkanals or alkanones.

These catalysts have an impact on the concentration of soot present in the fumes which is denoted by the Bacharach soot number. Comparing the soot resulting by burning clean fuel and fuel containing catalyst at $500 \mathrm{ppm}$ a decrease of soot emissions was observed by $41 \%$. In addition, soot coming from the catalytical combustion indicates lower corrosivity - $\mathrm{pH}$ of about 7 - towards the carbon black formed in the combustion process without a catalyst, which has a clearly acidic $\mathrm{pH}$ of 4 . Applied catalysts result in greater thermal stability of the fuel in relation to clean fuels and also affect the formation of solid residues in minor amounts at critical points in the combustion chamber [11].

The composition containing the additives selected from the group consisting of ferrocene and derivatives thereof causes a reduction of PM, improves (reduces) the number of excess air required in the combustion process. These catalysts increase the efficiency of combustion of liquid fuels while minimizing $\mathrm{NO}_{x}$ emissions, reducing corrosivity and the amount of particulate matter through which an increase in the efficiency of the system is accomplished [15].

The ferrocen catalyst introduced into the fuel consists of a substance belonging to the group of the following compounds:

- dicyclopentadienyliron, di(methylcyclopentadienyl)iron, di(ethylcyclopentadienyl)iron, methylferrocene, ethylferrocene, n-butylferrocene, dihexylferro- 
cene, phenylferrocene, m-tolylferrocene, didecylferrocene, dicyclohexylferrocene, dicyclopentylferrocene,

- an organic liquid carrier, in which ferrocene is soluble. Organic carrier is selected from the group consisting of high flash point aromatic solvents, hydrocarbon solvents and petroleum based solvents [12].

Catalysts used for the combustion of soot contain sodium chloride and ammonium chloride, and most important of all: hydrated copper sulfate, (Table 4).

Table 4 The composition of soot combustion catalyst [13]

\begin{tabular}{|c|c|}
\hline$[\%]$ & Ingredient \\
\hline 40 & $\mathrm{CuSO}_{4} \mathrm{aq}$ \\
\hline 52 & $\mathrm{NaCl}$ \\
\hline 3 & $\mathrm{NH}_{4} \mathrm{Cl}$ \\
\hline 5 & $\mathrm{Ca}(\mathrm{OH})_{2}$ \\
\hline
\end{tabular}

This invention relates to solid fuel compositions of enhanced performance properties of combustion characteristics. Coal, lignite, coal dust, coke and peat fired furnaces are used world-wide, so it has been necessary to find any particularly suitable additive to improve the combustion process of this kind of fuel. Significant fuel additives minimize the generation of soot and nevertheless can simplify the removal of furnace slag. In accordance with the embodiment of this invention presented in Table 4, soot minimization and throughout minimized origin of tarry substances are expected. This catalyst eliminates also the demand of mechanical supported scavenging of boilers, so that there is no need to downtime and no possibility for ignition of soot in smokestack. Furthermore, it reduces corrosion tendencies on steel elements of grate hearth, boilers and lead-off-installation for exhaust gases. This invention optimizes lifetime and efficiency of cyclone, filtres and electrofilters. A wide range of applications: operation on marine boats, heating plants, combined heat and power plants - therefore it should be improved [13].

\section{CONCLUSIONS}

Rising energy demand is directly related to the problem of inefficiency of the combustion process using fossil fuels.

Primarily the goal is to reduce pollution during its origin, and then to limit their emissions, if neccessary.

Limitation of emissions during their generation can be done through the use of catalysts of environmental protection. An appropriate catalyst selected for fuel 
enables an increase in the efficiency of oxidation processes while reducing pollution. Intensive research on new catalytic and, simultaneously, stoichiometric combustion processes is under way.

The priority is to minimize emissions of volatile organic compounds (VOC's), nitrogen oxides, sulfur oxides and carbon monoxide to a level which is technologically justified. By a technologically justified level is meant the level resulting from the application of the IPPC Directive concerning integrated pollution prevention and control [12]. It is connected directly to the grant of permission for the use of an integrated system/installation.

The subject is to get permission, which is related to the implementation of Best Available Techniques used for manufacturing. Such license shall be required in all industrial installations with high thresholds of emissions to the environment, including technological installations applied in fuel and energy industry,as well as chemical, mineral and also metallurgical industry, but also installations for waste management and municipal waste technology. Obtaining the permission is the first step - the next is a constant monitoring of parameters of changes and processes and their optimization, thus to preserve the integrated permit for the installation. The use of Best Available Techniques leads to the the establishment of such emission limits for which the relation between the benefits and costs of production is optimal [14].

Balance between processes and products is called the eco-efficiency of chemical processes. This value expresses the highest reasonable emission of pollutants into the environment. Appropriate preparation of substrates by pre-treatment is not a viable alternative to the possibility of returning harmful substances from exhaust stream. Possibility of recirculation is, however, conceivable only in closed production cycles.

The quality of life and quality of the environment or its improvement is primarily reflected by the composition of air, water and soil. Condition of these media is relevant to purification methods following the streams of by-products occurring in the chosen technology.

Reduction of emission is the overarching objective of EU policy, implemented through a number of legal acts and standards, but primarily through effects on consumer consciousness.

Promoting the quality of life by improving the environment as the first step, is likely to convince the user to run sustainable production processes, which are based on the optimal use of raw materials with a minimum load on ecosystem in a comprehensive approach. 


\section{ADDITIONAL INFORMATION}

This paper was prepared in the framework of the Operational Programme Innovative Economy 2007-2013 signed with the number POIG.01.04.00-16$159 / 12$

\section{REFERENCES}

1. Konstytucja RP z 2 kwietnia 1997.

2. Przemysł i handel naftowy w 2011 roku. Polska Organizacja Przemysłu i handlu naftowego.

3. Guziałowska-Tic J., Tic W. J.: Modyfikatory stosowane w procesie spalania olejów opałowych i paliw statych, Chemik, 66, 11 (2012), 1203-1210.

4. Dyrektywa parlamentu europejskiego i rady 2010/75/UE z dnia 24 listopada 2010 r. w sprawie emisji przemysłowych.

5. Karcz H., Jodkowski W., Nowakowski S., Sędzielowski E., Zabłocki W.: Ocena eksploatacyjna $i$ ekologiczna różnych konstrukcji olejowych palników energetycznych, Energetyka, 3 (2004), 179 -189.

6. Prawo Ochrony Srodowiska z 27.04.2001.

7. Protokół z Kioto, 1997.

8. Rozporządzenie Parlamentu Europejskiego i Rady (we) NR 595/2009 z dnia 18 czerwca 2009 r. dotyczące homologacji typu pojazdów silnikowych i silników w odniesieniu do emisji zanieczyszczeń pochodzących z pojazdów ciężarowych o dużej ładowności (Euro VI) oraz w sprawie dostępu do informacji dotyczących naprawy i obsługi technicznej pojazdów, zmieniające rozporządzenie (WE) nr 715/2007 i dyrektywę 2007/46/WE oraz uchylające dyrektywy 80/1269/EWG, 2005/55/WE i 2005/78/WE.

9. Pat. PL 179365 (1994).

10. Pat. EP 0476196 (1990).

11. Pat. US 18282 (1990).

12. Pat. EP 0359390 (1989).

13. Pat. PL 165406 (1991).

14. Dyrektywa Unii Europejskiej nr 96/61/WE z 24 września 1996 r. w sprawie zintegrowanego zapobiegania i zmniejszania zanieczyszczeń.

15. Zvereva E.R., Ganina L.V. Effects of additives on the working properties of furnance heavy fuel oil. Chemistry and Technology of Fuels and Oil, 45, 5 (2009), 349-353. 


\section{WPŁYW KATALIZATORÓW NA EMISJĘ ZANIECZYSZCZEŃ Z PROCESÓW SPALANIA PALIW CIEKŁYCH}

\section{Streszczenie}

Dynamiczny wzrost stosowania paliw nieodnawialnych dla celów energetycznych powoduje zapotrzebowanie na katalizatory poprawiające proces ich spalania. W pracy omówiono katalizatory stosowane głównie w procesach spalania paliw silnikowych i olejów opałowych. Katalizatory te pozwalają na podniesienie efektywności procesów utleniania powodując tym samym redukcję emisji zanieczyszczeń. Kluczem do sukcesu jest taki dobór składników katalizatora, który zapewni ograniczenie emisji szkodliwych produktów spalania do atmosfery.

Katalizatory wprowadzane są do strefy spalania jako roztwory mieszające się z paliwem, lub do powietrza dostarczanego do procesu spalania. W skład omawianych katalizatorów wchodza rozpuszczalne w paliwie: kompleksy metaloorganiczne, związki manganu, sole kawsów organicznych, ferrocen i jego pochodne oraz chorek sodu i chlorek magnezu odpowiedzialne za spalanie sadzy. Priorytetem jest minimalizacja emisji lotnych związków organicznych, tlenków azotu, tlenków siarki i tlenku węgla oraz cząstek stałych.

Słowa kluczowe: zanieczyszczenia powietrza, ochrona środowiska, emisja zanieczyszczeń, katalizator, pyły, sadza

Editor received the manuscript:16.03.2013 